\title{
Giving Away the Game - Scattershot Notes on Social Class and Other Afflictions
}

\author{
Jim Donnelly
}

\begin{abstract}
One of my earliest jobs was driving for an unregulated car service in New York. In the days before Uber they were called 'gypsy cabs.' One night I found myself on the business end of a revolver. Telling the tale to my dispatcher next day, he was staggeringly nonplussed. 'Ya gotta put up with a lot,' he said, 'when you're tryin' t' get ahead.' 'Yeah,' I replied, disgusted, 'even gettin' your head blown off.' Some time later, another driver, an African-American in a similar scenario, didn't make it, emphasizing how much higher the stakes for a person of color. These are the real wages of work, I thought, and the rules of the game.
\end{abstract}

My dispatcher's nonchalance bespoke how invested in the game he was; in a set of beliefs, assumptions, and animating myths that keep the wheel of fortune going. Like the Monty Python skit about the collapsing tower, if too few invest in those myths, the entire edifice crumbles.

The following is a personal essay that attempts to navigate the game's parameters - social class, aspiration, and its attendant neurosis - and the myths that animate such notions as 'getting ahead,' 'climbing the ladder,' and the 'American Dream,' my country's main (ideological) export. The approach is less theory-driven than empirical, phenomenological. Hence the numbered sections, a style popularized by Wittgenstein, Herbert Read and others. Here it doesn't represent chronology so much as the elusive, episodic nature of the beast.

\section{Keywords}

Social class, aspiration, working-class Italian Americans

1. My mother, a working-class Italian-American, forfeited her status as a result of manicdepression. In the early 1950s, around the time she finished high school, several studies were published $^{1}$ on the effects of downward mobility among ethnic groups. They found the Irish more or less where you'd expect, on Skid Row, in Bowery flop houses, with alcohol as cause and effect, a dark chaperone. Jewish downward mobility was more elusive - they couldn't seem to find any. Until they went with a hunch: What about psychiatric wards? Strong family dynamics and the rarity of heavy drinking found few Jews languishing on Skid Row. But a respect for therapeutic professions meant that institutions weren't stigmatized, the way they were for other groups.

Of course, the fortunate few needn't worry about downward mobility. When I was a young boy, my mother and I went to see the movie Mame, a story with tempting comparisons. If my

\footnotetext{
${ }^{1}$ There were a number of books on this theme, but I'm thinking mainly of A.B. Hollingshead and F.C. Redlich, Social Class and Mental Illness, Wiley and Sons, 1958
} 
mother had been a rich WASP, would she have been merely the Bohemian aunt, a lovable eccentric? Institutionalized several times, she came home to a family ill-equipped to define her problem. 'Josephine's high-strung,' her beleaguered parents would say, and I was forever warned that my mother was a 'sick woman.' There was always a smattering of peasant superstition in it, like 'Cellar-Lise' in Thomas Mann's Doctor Faustus, an abject crone living in a basement, rumored to be possessed. Even the enlightened, he tells us, hide their kids in their coattails lest Lise give them the 'evil eye.' Small comfort either way, the people in my mother's world were anything but enlightened.

But they were possessed. Possessed by that post-war monetary scramble of G.I. Bill, Eisenhower interstates, and movie-tone news showing sprawling Levittowns ${ }^{2}$ on erstwhile potato fields. The great auto-driven crush for that beachhead, the one that proclaimed if you weren't rich yet, you had a shot at it. You'd finally turned, in your spiffy Ford Fairlane, that long-promised corner to prosperity.

2. 'When Jim is dressed up, he looks like he owns a pool hall.' So spoke the resident of a senior center where I once worked. On a superficial level I took it as a compliment. Firstly because my tastes eschew Waspy blandness - wing-tip shoes, boring ties, blazers with elbow patches, etc. Secondly because hey, they said I looked like the hall's owner, not the resident leg-breaker. But on a deeper level it spoke the truth of the pecking order - it put me literally on the outskirts of town, far from the hallowed halls of finance, insurance, and real estate, at a remove from respectable institutions. I didn't much care what those men thought of me; beyond facile friendship, there wasn't much riding on it but minimum wage. At my level one didn't carry a reputation from job to job. But these were the proverbial organization men of the " $50 \mathrm{~s}$ and '60s, who had to grapple with the thorny trappings of reputation writ large. If they were anything other than 'other-directed,' in David Reisman's famous phrase ${ }^{3}$, they could risk job and career. In other words, you didn't show up for work looking like you owned a pool hall.

Why are we so fantastically uptight in America when it comes to the subject of class? Well, in a word, because it's everything. And unlike those other Americans to our north we don't plan to do anything about it (something like single-payer healthcare is a mechanism of redress.) So it remains the proverbial 500-pound gorilla, the thing hiding in plain sight we pretend isn't there. When speaking of race in America, James Baldwin famously compared it to a pair of friends chatting over coffee, one having murdered the mother of the other, her body hidden in the pantry. 'We can't talk about anything,' he said, 'because we can't talk about that. ${ }^{, 4}$ We can talk about very little in the U.S. because we won't truly admit class into the conversation.

3. I had a miserly aunt who used the same tea bags many times over. She'd literally hung a little line in her kitchen for drying them out. The tea they made was a barely beige water, like the landlady in Crime and Punishment. As a teenager I once brazenly quipped, 'Are you too cheap to give a person a lousy tea bag?' 'Mr. fancy-pants wants a new one,' she snarled. Sitting in her house in second-hand clothes, my mother and I on public assistance, I wondered who she was addressing. For her part she wasn't on a fixed income. Her son was a wealthy

\footnotetext{
${ }^{2}$ The first of several low-cost suburban housing developments built by Levitt and Sons following WWII, and accelerated by veterans' benefits.

${ }^{3}$ The Lonely Crowd, David Reisman, Nathan Glazer, Reuel Denney, Yale University Press, 1950

4This is from Baldwin's essay 'Notes for a Hypothetical Novel,' Nobody Knows My Name, Dial Press, 1961.

Further, on the intersection of race and class, see bell hooks, Where We Stand: Class Matters, Routledge, 2000; Angela Davis, Women, Race and Class, Vintage Books, 1981
} 
professional who doted on her, financially and otherwise. Knowing her status as a secondgeneration Italian-American, some, I suppose, might float the Memories of Privation argument.

But the demons of privation were so far in her past the cost of a tea bag wouldn't sate them. I was told she wasn't so miserly with everyone, so I suspect a less personal, more populist demon was at work: the demon of the undeserving poor. My mother and I had done nothing to 'rate' fresh tea. Worse yet, we were on public assistance, so perhaps it was her patriotic way of recapturing revenue, one tea bag at a time.

4. I had an uncle whose interest in a house was not so much the 'laughter and tranquility' Sinclair Lewis ${ }^{5}$ spoke of but its function as an outer, protective layer for his TV, namely Sunday football. A boy from the proverbial teeming tenements of wailing babes, bellowing drunks, feuding families and nosey neighbors, it's no wonder he saw the suburbs as Valhalla, particularly its funereal silence. Ensconced in a BarcaLounger, ${ }^{6}$ beer at the ready for kick-off, here was his American Dream. A man whose beginnings evoked those Life magazine images of socks and boxers on the line amongst the fire escapes, I never met a more devout dweller of the cul-de-sacs. When I'd complain of its isolation, its anomie, its carnivorous appetite for land and resources, better left for worthier things, he'd look at me like an evil heretic, blaspheming his savior. Isolation? He craved it. Anomie? Never heard of it. The appetite for land and resources? Why, that was the genius of capitalism at work, my boy. The more working stiffs you could take from the tenements and put into tract houses - and let's not forget 'nice' cars - the more the society could be called a success. 'Sure, some of Manson's followers came from suffocating suburbs but so have some of our finest actors.' He didn't actually say this, I only imagined he could have. While we're on it, some of our truly greatest talents James Cagney, Barbara Stanwyck, Steve Mcqueen, Rita Hayworth, Sidney Poitier, Clara Bow, Red Skelton, were from the teeming tenements, euphemistically or otherwise.

5. I remember the tedious talk of what constituted a 'nice' car while riding in the rear of some gaudy ocean liner: Lincoln Continental, Buick Riviera or Chrysler Caspian Sea, listening to the elders up front pontificate on the beauty and desirability of every brand, wondering, fleetingly, if you'd survive this excursion, emphasized by the accidents you'd sometimes pass. A city kid who knew the street as a venue for every sport, you'd had close calls with cars, and could recite the names of stolen friends. You knew also that every family had a story of vehicular loss. The lovely young daughter, her photo on the mantel, killed on a lonely road while at college. The harried father, moonlighting as a salesman, coming back from Boston like Willy Loman, falling asleep at the wheel. Or sometimes the living and maimed, prodded by young, morbid curiosity on your end and gin or medicated bravado on theirs, rattling off the particulars of their own brush with death, the grisly details in real time. Oddly the desire for a nice car superseded all this, for it made of status a traveling show. The idea of status doesn't mean much standing still - there aren't enough people to ogle it. But truly the only 'nice' car would be one that stood still, like the kiddie cars at the arcades, that bounce about on a spring, thereby sparing human life and the physical landscape. 'Nice' understood as something the opposite of ubiquitous, rapacious, and menacing. ${ }^{7}$

\footnotetext{
${ }^{5}$ In Babbit by Sinclair Lewis, Harcourt, Brace \& Co., 1922.

${ }^{6}$ 'BarcaLounger' was the original term for recliner, and a patented brand name. Americans used the terms interchangeably, much like 'Frigidaire' for refrigerator.

${ }^{7}$ There were over 36,000 car fatalities in the United States in 2019. In terms of yearly statistics, this is seen as a 'lesser' casualty rate! For more on motor vehicle mayhem, see The Car Culture, James J. Flink, M.I.T. Press, 1975; The Great American Motion Sickness, John Burby, Little, Brown and Co., 1971. On the relationship
} 
As I write this, in the midst of a hideous heat wave, a bulletin announces the cancellation of a NASCAR race in New Hampshire, due to the scorching temps. Not a note of irony as to the massive role played by the motorcar in climate change.

6. I grew up being told that the Soviet Union and the Eastern Bloc were the most lied-to societies on earth. There was the occasional perfunctory nod to Nazi Germany, but post-war rehabilitation was the order of the day, so the onus was on the Red bogeyman. Of course this was no accident; the German cartels ${ }^{8}$ that helped Hitler rise to power also financed his war. Nazi Germany was a capitalist country. The United States, its history, its ethics, its very raison d'etre made it the nexus of capitalism. European countries, both before and after Nazism, have had a complex relationship with free enterprise. German sociologist Werner Sombart's 1906 study 'Why is There No Socialism in the United States?' referred to America as a 'steeple chase...each against the other and all against all.' If he was only being figurative, there is everywhere the literal. There is always some World Series or Superbowl, always some summer or winter Olympic, always some marathon or competitive stunt to 'raise money.' In the 1980s, Reagan, 'the Gipper,' presided over his army of yuppies, hopped up on marching powder, a decade-long marathon of Gordon Geckoe, Dallas, and Lifestyles of the Rich and Famous. We've been on that page ever since. Of course propaganda can take many forms, not just the caricature of Big Brother and Orwellian garrets. Herbert Schiller referred to it as 'mind management,' and George Gerbner called it 'the symbolic atmosphere.' 9 Consider the noise machine of AM radio: 'I' $m$ the guy who made millions buying foreclosed homes and I'm gonna show you how!' followed by (erstwhile sports announcer) Rush Limbaugh... All of a piece.

7. A painful episode in my young life involved a Christmas 'Grab Bag' (In New England they call it a Yankee Swap.) Talking mom into it wasn't easy, as Welfare allowed nothing in the way of disposable income. I don't recall a financial exemption, but what's the more embarrassing, being too poor to contribute, or plunking down a crummy gift? I agonized over it - a paltry plastic gun from a pharmacy rack - and thought of pouncing on it myself to spare others the chagrin. I knew my classmates were well-off, but never had the chasm seemed so wide as that day, when a concrete display of buying power would lay my predicament bare for all to see - and ridicule. I wound up with a pricey paint set, something I had no interest in, but dimly aware its primary purpose was to flaunt a bank account.

I called it a painful episode, but I suffered no permanent damage from it, in fact I glean from its symbolic fount all the time. It's not often we live through an episode so full of ready touchstones. Most of what happens is scattershot, without rhyme or reason, a perplexing pastiche of events and observations - meaningless, or replete with meaning, depending on disposition. So terribly obvious is the grab bag episode it has the trappings of caricature. A school kid antes up for a holiday ritual where everyone gets a prize. He's poor and must conform to the fierce limits of a budget. He goes through an existential crisis, and considers pre-empting the lame excuse for a gift, thereby sparing his classmates. Rum luck, someone

\footnotetext{
between a car-dependent economy and suburban sprawl, see James Howard Kunstler, The Geography of Nowhere, Simon and Schuster, 1993.

${ }^{8}$ For more on this, any of Noam Chomsky's recorded talks on the subject (available on YouTube).

On I.G. Farben and the Holocaust, see Diarmuid Jeffreys, Hell's Cartel, Macmillan, 2008. More broadly on the corporate connection, see Nazi Nexus, Edwin Black, Dialog Press, 2017.

${ }^{9}$ Herbert Schiller, Mind Managers, Beacon Press, 1973; George Gerbner, 'The Symbolic Context of Action and Communication' from Contextualism and Understanding in Behaviorial Science, R.L. Rosnow, M. Georgoudi, Praeger, 1986
} 
beats him to it - the gift, and the trappings of his life, laid bare. The stuff of an award-winning young adult book, that parents read to their kids, rectitude all the way 'round.

8. To paraphrase H.L. Mencken, no one ever went broke underestimating the intelligence of the American public. To that could be added P.T. Barnum's quip regarding a sucker born every minute. Both sentiments apply to that most curious - and preposterous - of 60 s inventions, the plastic slipcover. 'Ya can't have nothin' nice,' we the children of the working class were always advised and admonished. Admonished especially when committing the crime of say, tossing a ball around a living room. To my surprise in my sarcastic quest around the internet, I found they're still being made and sold; in fact most of my findings were commercial boostership, very little in the way of critique. Memory via sense perception is often enough remarked upon, so suffice to say that the singular sensation of clear plastic sticking to you on a humid summer day is so many-splendored and evocative, evocative of the deep-seated neurosis of people desperate to preserve 'something nice,' even to the preclusion of its enjoyment.

Growing up we had only second and third-hand sofas, but my mom, at the urging of a zealous aunt, caught the plastic slipcover bug - or plague, I should say. The sofa was a light blue monstrosity with steep sides more like battlements than arm rests, custom-fitted to compensate. These detachable affairs were forever glued to your forearm or shoulder when you stood up, like unclaimed baggage. An elementary school friend, hearing me bemoan the slipcover scourge, weighed in.

'Yeah we had one of those on the couch 'til my dad got pissed and tore it off.'

'What happened?' I asked.

'He came home one night from the plant and wanted to lay on the couch and read the paper. came out of my room 'cuz I heard all this yelling. 'Goddamn it,' he says, 'I wanna feel fabric under me, not a goddamn shower curtain,' and he started ballin' it up and crammin' it in the trash. Mom says, 'Rich people preserve their furniture, why can't we?'

'Rich people don't put shower curtains on their sofas,' he says. 'Bill, when've you been in a rich person's house?' she says. And Dad says, 'Take my word for it.'

9. One of the great laboratories of class aspiration is the television car commercial (always some variation of one car with all the road, every road, to itself, an absurdity no one seems to notice). Of course this is the whole commercial schemata; the coveted object is yours alone and the world is yours entirely. I've been gently admonished by middle-class friends who'll say 'Really Jim, people are more sophisticated than that, no one takes these ads literally.' If so, if everyone is such an uber-sophisticate, then how can they sit still for such crap?

More pervasively, more insidiously, we've earmarked another word: freedom. ${ }^{10}$ Every politician genuflects to it, every Chief of Staff invokes it on the ramp-up to war, every school kid recites pledges to it, and every ad agency keeps it in their arsenal, such as a car manufacturer some years back. 'Freedom is calling you,' intoned a voice over the typical one-car, empty road scenario. Freedom in our culture is not a conceptualization but an article of faith, and, as with any quasi-religious tenet, it's tough to get people to question it, much less define it. Webster's Ninth Collegiate calls a concept 'a complex product of abstract or reflective

\footnotetext{
${ }^{10}$ On this most inscrutable of concepts, I recommend Maxine Green, The Dialectic of Freedom, Teacher's College Press, 1988, largely an American overview. For a more universal perspective, see Freedom:Its History, Nature and Varieties, Robert E. Dewey and James A. Gould, editors; Macmillan, 1970.
} 
thinking.' If Americans were to reflect on the ways they're supposedly free they'd also have to consider the ways they are most definitely not free.

Such as, most glaringly, the workplace, a feudalistic institution where Americans spend at least half their waking lives. I've been told at more than one paltry, dead-end job that if I didn't like the treatment, conditions, or pay I was 'free' to leave. Of course I was, and I remember that feeling of elation when I hit the street, a state-of-grace lasting all of five minutes. I was only as free as my churning gut and the landlord allowed me to be. I was, like so many others, free to die in the gutter, ragged and stinking, covered in sores and raving in delirium. Some freedom.

The twentieth century left us a ghastly iconography of unfreedom: gulags, concentration camps, Berlin Walls. Throw in what historians and sociologists have said regarding the complex of emotions around slavery - amongst white Americans, the ones that holler the loudest about freedom - and you've quite the Mulligan stew. The fact that all this can add up to an anxiety bordering on psychosis is illustrated by the hubbub over Obama's so-called 'FEMA trailers,'11 the specter of a Black president exacting revenge for the trials of his people.

Here we arrive at the subterranean trappings around the appeal of Donald Trump.

An enlightened person might see freedom as a sort of unfettered, unencumbered state of grace, intellectual and intuitive in equal measure. Freedom in America is a different animal in people's minds - like housing and health care, a marketing concept. Frank Zappa's Absolutely Free directed itself to the acquisitive ethos of the 1950s. The $80 \mathrm{~s}$ were a retrofitting, exemplified by Reagan's Brilliantine'd hair. Trump, a Reagan worshiper, is history's acid reflux, tragedy and farce as one indigestible lump. Trump's vulgar appeal is to freedom understood as doing anything that comes to mind. A mobster-like rich guy comes to the party, harasses the Mexican gardener, grabs the maid's pussy, ${ }^{12}$ then drunkenly takes a leak on the carpet. On the way out he slips you a fifty, winks, pats your back and says, 'No hard feelings.' The appeal is to the guy who'd like to do all of the above, minus the money gesture. That is, until his better (?) angel says, 'Don't beat yerself up, Bud...I mean it was a party, right? Tell ya wut - trow d'guy a fifty. Dat's class.' Money equals license, and license is what the culture is selling.

10. I recall a conversation in the early 90 s with a young guy, classifiably a hipster, about dwelling options in a rapidly gentrifying New York.

'Have you tried Jersey City?' I asked. 'It's a lightning commute to your job in Manhattan, got a lotta nice prewar buildings, hasn't been fully colonized...'

'Yeah,' he said, 'A friend o'mine moved out there so I thought I'd check it out. I took a walk around the neighborhood...Wow man, pretty sketchy.'

The word was new to me at that juncture, being ten years his senior, but I knew it to have a negative slant. Wiktionary tells us 'sketchy' describes something 'creepy, iffy...an air of uncertainty...and just generally something or someone you don't want to be associated with...' Webster's primary definition is 'something not clearly defined.' I lived in Jersey City in the 1980s and it was anything but sketchy. Its problems were there in bold relief, another white flight casualty, left for dead like other peripheral cities. I was living there at the same level as

\footnotetext{
${ }^{11}$ See https://thehill.com/policy/healthcare/107109-lawmakers-raise-concerns-with-contaminated-fema-trailershousing-oil-spill-clean-up-crews

${ }^{12}$ I apologize for the term, but I wanted the image to reflect Trump's singular vulgarity.
} 
its denizens, in a roach-infested flat, slogging away at a dead-end job, before the requisite hipsters, yupsters, life coaches, aspiring screen writers, dog walkers and cupcakeries had arrived to neutralize its sketchiness. Or, more accurately, bulldoze ${ }^{13}$ its problems out of sight, hence out of

mind.

11. Social class abides by a kind of unacknowledged mysticism, an extension and articulation of the functional mysticism around money. Investigations into the architecture of money, from its function as 'legal tender' to its preeminent position in capital formation, illustrate how money seemingly moves of its own accord. But we needn't go all the way left to understand the contours of money mysticism. Economists of every stripe avow there's nothing 'inherently' valuable about money. According to Alan Gotthardt:

Money has no intrinsic value, only relative value. Its worth is measured by the ability to exchange it for something of value to the owner. In this light, the man who has no money and no wants is in the same position as one who has all the money in the world but cannot buy what he wants. In both cases, money is irrelevant because it cannot accomplish its purpose. ${ }^{14}$

Marx spoke of the 'dazzling money form,' ${ }^{15}$ referring to the conversion of coins into commodities, a further remove from barter, an exchange form that cleaves closer to vital necessity. With commodities comes design, and with design comes aesthetics, and this brings us closer to what makes people itchy when it comes to class.

But of course aesthetics, that which meets the eye, is really the core of our inquiry. Aesthetics - and sense perception. I knew a fellow who drank only small-batch brandy because 'Remy? That's mass-produced swill.' Someone else won't drink Bud, while someone down the block (or down the bar) won't drink a particular beer because it's not 'cottage' enough. (Blue bloods think all beer is gauche.) Some won't live in a house with less than three bathrooms. Some will break the bank for a cramped flat if it's in a swank neighborhood. Someone else thinks it's brutish and tacky to rev one's engine, while others think it's snooty to notice. Some people are impressed by tuxedoes, and if you point out the wealthy abandoned them long ago - except for isolated occasions - you're accused of inverse snobbery. Some people would be impressed if they saw a man in a tuxedo on a subway. Some would wonder: why the subway? Some would remain impressed even if he picked his nose, scratched his ass, and spoke in a thick Bronx accent. If you pointed out such behaviors as low-brow, conduct unbecoming a dinner jacket, you might be thought jealous. Some people think having a hothouse tan, sitting on a throne, and chanting 'Lock her up!' is class. Others think you're a snob if you're too good to

\footnotetext{
${ }^{13}$ On the problems of gentrification and who it leaves behind, see Peter Moskowitz, How to Kill a City: Gentrification, Inequality and the Fight for the Neighborhood, Public Affairs, 2017. 'Bulldoze,' is hardly a metaphor. As stated earlier, I grew up on public assistance, living in Black majority communities in both New York and Atlanta. I recently found out, to my horror, that all of Atlanta's public housing projects have been demolished. This includes the Capitol Homes, where my mother and I lived in the 1970's. She, an indigent single mom, often swapped baby sitting duties with other single moms. The Atlanta Housing Authority, touting new 'mixed income' units and vouchers, has not so much guaranteed resettlement for former tenants as abandoned them to market roulette. See 'Who Benefits When Public Housing is Torn Down,' Mother Jones, March 24, 2020; 'Atlanta Housing Demolition Sparks Outcry,' March 10, 2008, www.npr.org

${ }^{14}$ Alan Gotthardt, The Eternity Portfolio, Tyndale House, 2003. Gotthardt is a Christian investment and philanthropy guru.

${ }^{15}$ In Capital Volume One, Section Three: The Form of Value or Exchange Value.
} 
have a lover in jail. It's just such triangulation that makes the subject of social class so maddeningly difficult to write about. ${ }^{16}$

12. I have a unique vantage point when it comes to the question of social rankings because I host a monthly reading series. Introduced in this way writers quickly become deferential, as I have something they desire - a chance at an audience. So it's interesting to see a sudden rise in my prestige as formalities progress. This does nothing to change my social status of course, though there's the assumption that I possess an MFA or a degree in literature. I don't. The only certificate I hold is a GED. ${ }^{17}$

I came from behind the podium at a feature reading in New York many years ago to lavish praise from a woman in attendance. I was on a double bill with another writer, and out of a kind of rote courtesy she praised him as well. It was obviously superficial, obviously a blind, and regretfully for her she'd dialed the wrong number with Bobby, a working-class tough from the Bronx. 'Yeah, yeah right...' he blurted gruffly, literally pushing her to one side as he headed for the snack table. This left me standing with this starchy, librarian-like woman awkwardly trading niceties, grateful for any interruption that happened by. That came in the form of another colleague, who let slip that I hosted readings.

'Oh? Do you...?' she queried, the previous incident already fading in importance.

'Yes,' I answered, with false conviviality, 'Are you a writer as well?'

'Well I've appeared in some small publications...' Here she glanced uneasily over her shoulder. 'I hope I haven't offended your friend; he is your friend, isn't he?'

'An acquaintance. And I'm sure he'll recover.'

Not only did this set her at ease, she doubled down on her self-promotion, hardly missing a beat. (I've always been amazed at how seamlessly the middle-class can stay on task. They are, after all, the class most trained in the art of negotiation.) She was attractive, and because Bobby was always after a new conquest, or cheering on someone else's, I could see him ogling us from across the room. She intercepted this, putting her back off balance. We parted with her having secured a feature, but not without her looking back quizzically, trying to square, I suppose, my seemingly suave demeanor with my choice of friends. While adept at aping the trappings of bourgeois etiquette when the occasion demands, get me angry and I'm back among the street urchins. Anger, like sitting down to eat, will always betray class origins.

13. Social classification is the first resource in a society based on appearances. On a bus, on an elevator, at a party, we are continually classifying and categorizing those around us. Some of this is deep anthropology - the fight-or-flight instinct seeking its parameters. But in modern American society it is barometric, determining whether we behave warmly or coolly to our peers. As Lionel Trilling put it, in 'Manners, Morals, and the Novel:' ${ }^{18}$

Snobbery is pride in status without pride in function. And it is an uneasy pride of status. It always asks 'Do I belong - do I really belong? And does he belong? And if I am observed talking to him, will it make me seem to belong or not to belong?' It is the

\footnotetext{
${ }^{16}$ On the conundrum of taste, 'lifestyle' (a loathsome term) and what clothing communicates, still the best and most entertaining is Paul Fussell's Class, Simon and Schuster, 1983.

${ }^{17}$ General Equivalency Diploma - a welcome recourse for drop-outs and someone like me, missing school time due to family disruption.

${ }^{18}$ Lionel Trilling, Manners, Morals, and the Novel, The Kenyon Review, Vol. 10, No. 1 (Winter, 1948), pp. 1127.
} 
peculiar vice not of aristocratic societies which have their own appropriate vices, but of bourgeois democratic societies...The dominant emotions of snobbery are uneasiness, self-consciousness, self-defensiveness...

...In a shifting society great emphasis is put upon appearance - I am using the word now in the common meaning, as when people say that 'a good appearance is very important in getting a job.' To appear to be established is one of the ways of becoming established...status in a democratic society is presumed to come not with power but with the tokens of power...

Inadvertently I've tested this theory of appearances. I have a number of vintage blazers that I wear on occasion. In combination with an antique tie, dress slacks and shoes, I've been referred to as 'sharp.' In fashionista New York I'd be seen as a curio. In the small town where I live the petty bourgeois mistake me for a professional; my fellow proles think I'm the enemy. Triangulation again...

One day I held the door of a thrift shop for a woman loaded down with bounty. I didn't realize I had a small item - a tie clasp - in my hand, and obliviously I walked out with it. For a moment I considered boosting it, but want no longer dictates need so I re-entered the shop and forthrightly told the cashier what occurred.

'It's only two dollars sir,' she said, looking about furtively for her superiors. 'Just go 'head and take it.'

Her eyes flashed coquettishly as she folded my hand around the tie clasp. I could congratulate myself on my magnetism, but it was the suit that did it. As far as stealing goes, I just didn't fit her profile.

14. My working-class family's obsession with money was a thing to behold, not for the squeamish. As I said earlier, they were part of that mad post-war scramble, and by sheer will and 'hustle' they managed to shoulder their way into the middle-class - financially at least. A few went further, marrying into the upper middle-class and mimicking its cultural trappings. To walk the walk and talk the talk; after all, the procedural signposts are everywhere available, on TV, in the movies, in ads in magazines. There are even coaches now, teaching the affectations of the manor-born. But why spend? Get even a low-level job at an insurance firm or trade magazine, attend some company parties, and you'll get a crash course. But back in the hollows, where the real fireworks over finance take place, the attitude towards money and its powers can only be described as, well, grubby. There were some in my family that weren't above deception, subterfuge, and outright theft to get their hands on the stuff. I've been amongst the very rich and they aren't obsessed with money. Leisure is their obsession. 'Yes,' some will say, 'but money buys leisure.' And with that they display their tedious middleclassness. Such an observation is procedural in nature - that, like taxes, they leave to the rest of us. Particularly the middle-class, who are so willing to scramble about and keep the aspirational facade up and running. The upper class doesn't bother.

15. The other day I watched a news clip of a basketball player being interviewed post-game on the court. His jersey had a Nike logo in one corner and another logo (Who knows? Who cares?) on the other. He mopped his sweat with a 'Gatorade' towel. The arena itself, I'm sure, sported the name of some corporate entity. Gone are the days when they were named for civic figures. We don't seem to ask why, or even when, this happened, because as Gore Vidal put it, we are the 'United States of Amnesia.' On a deeper level it represents our full-on surrender to 
commercialism's dictates, a kind of brute osmosis into every corner of life. We fail to notice, of course, because we've become the product. Consider the stencils on truck cabs like 'Silly boy, trucks are for girls,' or the ubiquitous pissing urchin, letting go on the brand most reviled. Or vanity license plates that mimic some advertising pitch. A man where I worked told a tale of his late professional father, who would host the proverbial cocktail party for his colleagues - a semi-private, semi-professional affair undertaken for career advancement. (The novels of John P. Marquand come to mind.) One evening the gentlemen - and in those days it was exclusively a men's club - discussed automotive renown.

'Y'know, Chet, the Crown Victoria is every bit as good as a Cadillac, dollar for dollar, and leaves a lot more in your pocket for other things...' essaying a go at practicality over prestige.

But his father, the higher-up of the two, gently set his underling straight, with a declamatory quip right from a big-three car ad, cleverly combining an oddly commercialized common sense with the obligation to climb the corporate ladder.

'Maybe so, Andy,' he said, 'but what would you really rather drive?'

\section{Author Bio}

Jim Donnelly is a former trucker, forklift operator, warehouse worker, and union organizer. A writer and musician, he wrote a monthly column called 'Media Misinformation' for the Aquarian Weekly. He now provides education and entertainment to elder communities. His two collections of poetry are published by Moon Pie Press, Maine and he has creative nonfiction forthcoming in issue \#8 of Lumpen, a UK journal for marginalized writers. 